\title{
ГОСПОДАРСЬКО-ПРАВОВЕ РЕГУЛЮВАННЯ БІРЖОВОЇ ТОРГІВЛІ СІЛЬСЬКОГОСПОДАРСЬКОЮ ПРОДУКЦІЮЮ: АНАЛІЗ МІЖНАРОДНОГО ТА НАЦІОНАЛЬНОГО ЗАКОНОДАВСТВА
}

\section{Бондарчук А. М.}

\section{ВСТУП}

Біржова торгівля сільськогосподарською продукцією як особливий вид господарської діяльності характеризується переважно самоврядним та саморегульованим характером, однак суспільні правовідносини, які водночас складаються між учасниками торгів, а також які виникають у сфері організації біржової торгівлі, потребують державного регулювання, однією $з$ форм якого є правове регулювання. У даному контексті варто зауважити, що належне правове регулювання біржової торгівлі $\epsilon$ необхідною умовою для захисту прав та інтересів усіх учасників правовідносин, дотримання ними встановлених правил та стандартів у зазначеній сфері, сталого й ефективного розвитку біржових механізмів реалізації сільськогосподарської продукції.

Водночас, попри важливість державного регулювання біржової діяльності, необхідно враховувати, що таке регулювання має відповідати засадам нової державної регуляторної політики, яка полягає в поступовому зниженні державного втручання в господарську діяльність (політика дерегуляції) та переході суб'єктів господарювання переважно на саморегульовану основу діяльності.

Окремі питання організації та здійснення біржової торгівлі сільськогосподарською продукцією досліджували такі науковці, як: Т.В. Боровик, А.М. Гура, Є.М. Кирилюк, В.М. Корнієнко, І.В. Лещук, Ю.С. Ліщук, І.О. Седікова, Т.В. Стойко, О.В. Томчук, В.О. Яворська й ін. Однак господарсько-правові аспекти організації та здійснення біржової торгівлі сільськогосподарською продукцією недостатньо досліджені у вітчизняній науці господарського права, зокрема, майже немає робіт, присвячених аналізу міжнародного та національного законодавства в цій сфері з урахуванням сучасного стану розвитку суспільних правовідносин.

У зв'язку із цим метою наукової роботи $\epsilon$ проведення аналізу господарсько-правового регулювання біржової торгівлі сільськогосподарською продукцією та визначення на цій підставі сучасного стану та перспектив розвитку господарського законодавства в цій сфері. 


\section{1. Міжнародно-правові та концептуально-правові засади організації біржової торгівлі сільськогосподарською продукцією}

Щоби визначити сучасний стан правового регулювання біржової торгівлі сільськогосподарською продукцією, передусім варто вказати на те, що Україна в цій сфері прийняла міжнародні зобов'язання, з урахуванням яких і має здійснюватися подальший розвиток правових засад.

Зокрема, в Угоді про асоціацію України з Свропейським Союзом (далі СC) передбачено співробітництво сторін із метою сприяння розвитку сільського господарства та сільських територій, зокрема, шляхом поступового зближення політик та законодавства (ст. 403) ${ }^{1}$.

До міжнародних актів у сфері регулювання торгівлі сільськогосподарською продукцією можна віднести Угоду Світової організації торгівлі (далі - СОТ) про сільське господарство ${ }^{2}$, Угоду СОТ про застосування санітарних та фітосанітарних заходів від 15 квітня 1994 р. ${ }^{3}$, Міжнародну конвенцію про захист рослин ${ }^{4}$, до якої Україна приєдналась у 2006 p. ${ }^{5}$, Директиву Ради 2000/29/€С про заходи захисту від інтродукції на територію Спільноти організмів, шкідливих для рослин або рослинних продуктів, та від їх поширення на території Спільноти, зі змінами, внесеними зазначеними нижче Директивами (преамбула пропущена) ${ }^{6}$ та ін.

Вказані міжнародні акти спрямовані переважно на закріплення міжнародних вимог та стандартів щодо вирощування сільськогосподарської продукції, іiї якості та переробки, захисту національних сільгоспвиробників від надмірного експорту, для чого дозволяється запроваджувати квоти на експорт сільськогосподарської продукції тощо.

Зокрема, в Угоді про сільське господарство передбачено, що сторони, укладаючи цю угоду, прагнуть досягти конкретних обов'язкових зобов'язань у кожній із таких сфер: доступу до ринку; національної підтримки; експортної конкуренції, а також досягти угоди стосовно санітарних і фітосанітарних питань ${ }^{7}$.

\footnotetext{
1 Угода про асоціацію між Україною, з однієї сторони, та Європейським Союзом, Європейським співтовариством з атомної енергії і їхніми державами-членами, з іншої сторони, від 27 червня 2014 р. URL: https://zakon.rada.gov.ua/laws/show/984_011.

${ }^{2}$ Угода про сільське господарство від 15 квітня 1994 р. URL: https://zakon.rada.gov.ua/laws/ show/981_005.

3 Угода про застосування санітарних та фітосанітарних заходів від 15 квітня 1994 p. URL: http://zakon5.rada.gov.ua/laws/show/981_006.

4 Міжнародна конвенція про захист рослин від 6 грудня 1951 p. URL: https://zakon.rada.gov.ua/laws/ show/995_805.

5 Про приєднання України до Міжнародної конвенції про захист рослин : Указ Президента України від 31 січня 2006 р. № 81/2006. URL: https://zakon.rada.gov.ua/laws/show/81/2006.

6 Директива Ради 2000/29/СС про заходи захисту від інтродукції на територію Спільноти організмів, шкідливих для рослин або рослинних продуктів, та від їхнього поширення на території Спільноти зі змінами, внесеними зазначеними нижче Директивами (преамбула пропущена), від 8 травня 2000 р. ОВ № L169. 10.07.2000. c. 1-112. URL : http://www.fitolab.volyn.ua/images/direktivy.pdf.

7 Угода про сільське господарство від 15 квітня 1994 p. URL: https://zakon.rada.gov.ua/laws/ show/981_005.
} 
Хоча у згаданій Угоді не йдеться безпосередньо про розвиток такої форми реалізації сільськогосподарської продукції, як біржова торгівля, однак, виходячи $з$ необхідності забезпечення максимальної доступності до ринку сільгосппродукції, сприяння розвитку конкурентоспроможності сільгоспвиробників, що закладено в цій Угоді, а також зважаючи на визначені в Угоді про асоціацію України та ЄС засади співробітництва у сфері сільського господарства, варто констатувати, що розвиток біржової торгівлі сільськогосподарською продукцією $є$ метою, сумісною 3 міжнародними зобов'язаннями України.

Варто зазначити, що 25 липня 2007 p. секретаріатом Організації Об'єднаних Націй (далі - ООН) за результатом проведеної конференції 3 питань торгівлі та розвитку складено узагальнену довідку «Про роль розвитку біржової діяльності» ${ }^{8}$. У цьому документі визначена роль товарних бірж як інститутів, що сприяють торгівлі та можуть каталізувати зростання товарних секторів країн, що розвиваються, завдяки значному зменшенню трансакційних витрат товарного ланцюга поставок.

Важливо також, що в довідці проводиться аналіз оптимального поєднання засобів державного регулювання організованого біржового ринку та саморегулювання в цій сфері. Зокрема зазначається, що визначення оптимальності регулювання залежить значною мірою від рівня впевненості, якої вимагають учасники ринку. Отже, ринки з усталеною практикою, відносинами та добропорядністю між учасниками потребують більш гнучкої, полегшеної моделі державного регулювання, ніж ринки, на яких учасники незнайомі 3 ринковими інститутами, контрагентами та процедурами. Необхідний баланс також полягає в оптимальному поєднанні державного регулювання, що здійснюється компетентними державними органами, та саморегулювання 3 боку представницьких органів - саморегулівних організацій (останні зазвичай працюють за правилами, які визначаються державними органами). Водночас уважається, що оптимальний баланс демонструють Сполучені Штати Америки (далі - США) ${ }^{9}$.

Отже, міжнародні акти у сфері регулювання торгівлі сільськогосподарською продукцією здебільшого визначають міжнародні стандарти, що висуваються до якості сільськогосподарської продукції, зокрема й вимоги до іï вирощування та переробки, допустимі норми використання пестицидів та гербіцидів у сільському господарстві, а також окремі питання експорту й імпорту відповідної продукції. Основною

\footnotetext{
${ }^{8}$ The development role of commodity exchanges : United Nations Conference on Trade and Development TD/B/COM.1/EM.33/2. 25 June 2007. URL: https://unctad.org/en/Docs/c1em33d2_en.pdf.

${ }^{9}$ The development role of commodity exchanges : United Nations Conference on Trade and Development TD/B/COM.1/EM.33/2. 25 June 2007. URL: https://unctad.org/en/Docs/c1em33d2_en.pdf.
} 
метою міжнародного регулювання в цій сфері $є$ встановлення єдиних (уніфікованих) правил обігу сільськогосподарської продукції, яка відповідає визначеним критеріям якості, що $\epsilon$ основною умовою для формування відкритого ринку. В аспекті розвитку біржової торгівлі сільськогосподарською продукцією йдеться про формування єдиного біржового ринку.

В Україні концептуально-правові питання розвитку біржової торгівлі сільськогосподарською продукцією постали ще на початку розбудови державності, що зумовлено стратегічною важливістю сільського господарства для розвитку національної економіки.

Так, однією з перших у цій сфері була постанова Кабінету Міністрів України від 17 листопада 1995 р. № 916 «Про прискорення організації біржового сільськогосподарського ринку» ${ }^{10}$, яка визначила біржовий сільськогосподарський ринок як взаємопов'язану систему державних, біржових та інших структур сільськогосподарського ринку згідно 3 наведеною схемою, яка включає Міністерство аграрної політики України, Українську аграрну біржу, брокерів, банки, інвесторів, сільгоспвиробників та інших суб'єктів, між якими встановлені взаємозв'язки. Одним із завдань, визначених постановою, є підвищення ефективності реалізації сільськогосподарської продукції та досягнення паритету цін на продукцію сільського господарства і промисловості.

У 1997 р. постановою Кабінету Міністрів України № 848 затверджено Концепцію розвитку біржового ринку сільськогосподарської продукції ${ }^{11}$, яка ставила такі цілі, як: розроблення механізму вдосконалення відносин між сільськогосподарськими товаровиробниками й іншими операторами ринку; визначення механізму відносин на біржовому ринку в умовах приватизації зернових елеваторів; опрацювання методів застосування сучасних технологій біржової торгівлі для формування оптового ринку сільськогосподарської продукції тощо.

Більшість із поставлений цілей не було досягнуто, про що свідчить занепад галузі сільськогосподарського виробництва та відсутність фактичних результатів у сфері формування організованого біржового ринку.

3 метою вирішення завдання щодо подолання кризових явищ у галузі сільськогосподарського виробництва ухвалено низку указів Президента України, зокрема: від 6 червня 2000 р. № 767/2000 «Про заходи щодо

10 Про прискорення організації біржового сільськогосподарського ринку : постанова Кабінету Міністрів України від 17 листопада 1995 р. № 916. URL: https://zakon.rada.gov.ua/laws/show/916-95$\% \mathrm{D} 0 \% \mathrm{BF}$.

11 Про Концепцію розвитку біржового ринку сільськогосподарської продукції : постанова Кабінету Міністрів України від 5 серпня 1997 р. № 848. URL: https://zakon.rada.gov.ua/laws/show/848-97-\%D0\%BF. 
забезпечення формування та функціонування аграрного ринку» ${ }^{12}$, від 8 серпня 2002 р. № 694/2002 «Про заходи щодо прискорення розвитку аграрного ринку» ${ }^{13}$, від 19 травня 2003 р. № 415/2003 «Про додаткові заходи щодо стабілізації ринку зерна» ${ }^{14}$. Ці укази визначали шляхи подальшого розвитку галузі сільськогосподарського виробництва, водночас акцентували увагу на необхідності стимулювання сільськогосподарських товаровиробників до участі в біржовій торгівлі, здійсненні закупівлі сільськогосподарської продукції та продовольства для державних i регіональних потреб на конкурентних засадах, включаючи закупівлю на товарних біржах.

Наприкінці 2015 р. розпорядженням Кабінету Міністрів України схвалено Концепцію Державної цільової програми розвитку аграрного сектора економіки на період до $2022 \mathrm{p.}^{15}$

Серед проблем, посталих у нинішніх умовах, на вирішення яких спрямована дія Концепції, визначено необхідність поліпшення умов ведення бізнесу, проведення якісних перетворень, здатних забезпечити підвищення конкурентоспроможності сільськогосподарського виробництва на внутрішньому та зовнішньому ринку, продовольчу безпеку держави, наближення до європейської політики у сфері сільського господарства, вирішення питання адаптації сільськогосподарських товаровиробників до умов роботи у глобалізованому економічному середовищі з урахуванням формування зони вільної торгівлі з державамичленами $\mathrm{CС} \mathrm{тощо.}$

Характерно, що одним із завдань розвитку біржового ринку в Концепції визначено запровадження фінансових та інших інструментів на ринку сільськогосподарської продукції (аграрні розписки, ф'ючерсні і форвардні контракти тощо) ${ }^{16}$.

Отже, розвиток біржової торгівлі сільськогосподарською продукцією визнається стратегічним завданням вітчизняної економіки загалом та господарського законодавства зокрема.

\footnotetext{
${ }^{12}$ Про заходи щодо забезпечення формування та функціонування аграрного ринку : Указ Президента України від 6 червня 2000 р. № 767/2000. URL: https://zakon.rada.gov.ua/laws/show/767/2000.

${ }^{13}$ Про заходи щодо прискорення розвитку аграрного ринку : Указ Президента України від 8 серпня 2002 p. № 694/2002. URL: https://zakon.rada.gov.ua/laws/show/694/2002.

14 Про додаткові заходи щодо стабілізації ринку зерна : Указ Президента України від 19 травня 2003 p. № 415/2003. URL: https://zakon.rada.gov.ua/laws/show/415/2003.

15 Про схвалення Концепції Державної цільової програми розвитку аграрного сектору економіки на період до 2022 р. : розпорядження Кабінету Міністрів України від 30 грудня 2015 р. № 1437-p. URL: http://zakon3.rada.gov.ua/laws/show/1437-2015-\%D1\%80.

${ }^{16}$ Про схвалення Концепції Державної цільової програми розвитку аграрного сектора економіки на період до 2022 р. : розпорядження Кабінету Міністрів України від 30 грудня 2015 р. № 1437-p. URL: http://zakon3.rada.gov.ua/laws/show/1437-2015-\%D1\%80.
} 


\section{2. Загальні засади господарсько-правового регулювання біржової торгівлі сільськогосподарською продукцією в Україні}

Переходячи безпосередньо до аналізу національного законодавства у сфері регулювання біржової торгівлі сільськогосподарською продукцією, необхідно погодитись із думкою В.I. Лебеденка, який зазначає, що особливістю господарського законодавство $\epsilon$ його комплексний сегментарний характер, оскільки система такого законодавства складається iз значного масиву взаємопов'язаних законодавчих та нормативноправових актів різної юридичної сили та галузевої належності, які загалом або окремі положення яких безпосередньо або опосередковано регулюють господарські правовідносини ${ }^{17}$.

Комплексний характер господарського законодавства у сфері регулювання біржової торгівлі сільськогосподарською продукцією виражається в наявності розгалуженої системи законів та підзаконних нормативно-правових актів, що регламентують зазначену сферу економічних правовідносин, а також у тому, що зазначена система нормативно-правових актів регулює не тільки господарські, але й інші суміжні правовідносини, що виникають у сфері біржової торгівлі сільськогосподарською продукцією.

Так, правовою основою організації біржової торгівлі сільськогосподарською продукцією в Україні $є$ Господарський кодекс України (далі - ГК України $)^{18}$, закони України «Про товарну біржу» ${ }^{19}$, «Про зерно та ринок зерна в Україні» ${ }^{20}$, «Про державну підтримку сільського господарства України» ${ }^{21}$, «Про особливості страхування сільськогосподарської продукції 3 державною підтримкою» ${ }^{22}$, постанови Кабінету Міністрів України від 19 грудня 1997 р. № 1417 «Про затвердження Порядку формування обсягів сільськогосподарської продукції i продовольства для державних потреб та їх реалізації $з$ державних ресурсів через біржовий товарний ринок» 23 , від 26 грудня 2005 р. № 1285 «ро

\footnotetext{
17 Лебеденко В. Господарське законодавство: комплексний сегментарний інститут господарського права. Науковий вісник Міжнародного гуманітарного університету. Серія «Юриспруденція». 2013. № 6-2. Т. 2. С. 27.

${ }^{18}$ Господарський кодекс України від 16 січня 2003 р. № 436-IV. URL: https://zakon.rada.gov.ua/laws/ show/436-15.

${ }^{19}$ Про товарну біржу : Закон України від 10 грудня 1991 р. № 1956-XII. URL: https://zakon.rada.gov.ua/ laws/show/1956-12.

${ }^{20}$ Про зерно та ринок зерна в Україні : Закон України від 4 липня 2002 р. № 37-IV. URL: https://zakon.rada.gov.ua/laws/show/37-15.

${ }^{21}$ Про державну підтримку сільського господарства України: Закон України від 24 червня 2004 р. № 1877-IV. URL: https://zakon.rada.gov.ua/laws/show/1877-15.

22 Про особливості страхування сільськогосподарської продукції з державною підтримкою : Закон України від 9 лютого 2012 р. № 4391-VI. URL: https://zakon.rada.gov.ua/laws/show/4391-17.

23 Про затвердження Порядку формування обсягів сільськогосподарської продукції і продовольства для державних потреб та їх реалізації з державних ресурсів через біржовий товарний ринок : постанова
} 
створення Аграрної біржі», якою затверджено Статут аграрної біржі ${ }^{24}$, від 24 лютого 2010 р. № 196 «Деякі питання Аграрної біржі», якою затверджено Положення про наглядову раду Аграрної біржі ${ }^{25}$, наказ Міністерства економічного розвитку і торгівлі України від 21 листопада 2012 р. № 1327 «Про затвердження Порядку організації та проведення конкурсного відбору товарних бірж для закупівлі матеріальних цінностей до державного матеріального резерву» ${ }^{26}$ тощо.

ГК України - кодифікований акт господарського законодавства, який регулює загальні питання біржової торгівлі, зокрема: особливості укладання господарських договорів на біржах, загальні засади здійснення торгово-біржової діяльності, господарсько-правовий статус товарної біржі, правові умови іiі функціонування, права та обов'язки товарної біржі, основні вимоги, що висуваються до правил біржової торгівлі, припинення товарної біржі тощо.

Водночас ГК України не визначено особливості біржової торгівлі саме сільськогосподарською продукцією, однак, виходячи з того, що предметом біржової торгівлі $\epsilon$ біржові контракти, базовим активом яких $\epsilon$ сільськогосподарська продукція, можна зробити висновок, що загальні ознаки господарської діяльності товарної біржі властиві і цій сфері, а відмінність полягає в більш вузькому предметі.

Зокрема, у ст. 278 ГК України визначається, що здійснення торговельнобіржової діяльності має на меті організацію та регулювання торгівлі шляхом надання послуг суб'єктам господарювання у здійсненні ними торговельних операцій спеціально створеною господарською організацією - товарною біржою ${ }^{27}$. До основних обов'язків товарної біржі віднесено: створення умов для проведення біржової торгівлі; регулювання біржових операцій; регулювання ціни на товари, що допускаються до обігу на біржі; надання членам і відвідувачам біржі організаційних, інформаційних та інших послуг тощо.

Деталізація положень ГК України в частині регулювання діяльності товарної біржі міститься в Законі України «Про товарну біржу».

Кабінету Міністрів України від 19 грудня 1997 р. № 1417. URL: https://zakon.rada.gov.ua/laws/show/1417$97-\% \mathrm{D} 0 \% \mathrm{BF}$.

${ }^{24}$ Про створення Аграрної біржі : постанова Кабінету Міністрів України від 26 грудня 2005 р. № 1285. URL: https://zakon.rada.gov.ua/laws/show/1285-2005-\%D0\%BF.

${ }^{25}$ Деякі питання Аграрної біржі : постанова Кабінету Міністрів України від 24 лютого 2010 р. № 196. URL: https://zakon.rada.gov.ua/laws/show/196-2010-\%D0\%BF.

26 Про затвердження Порядку організації та проведення конкурсного відбору товарних бірж для закупівлі матеріальних цінностей до державного матеріального резерву : наказ Міністерства економічного розвитку і торгівлі України від 21 листопада 2012 p. № 1327. URL: https://zakon.rada.gov.ua/ laws/show/z2070-12.

27 Господарський кодекс України від 16 січня 2003 р. № 436-IV. URL: https://zakon.rada.gov.ua/ laws/show/436-15. 
Під час проведення аналізу положень цього Закону передусім варто зауважити, що він ухвалений ще в 1992 р., 3 деякими змінами та доповненнями залишається чинним i натепер. Про застарілість його положень свідчить відсутність норм, що регулюють укладення на товарній біржі строкових угод, порядок проведення торгів за допомогою цифрових технологій, здійснення розрахунків за допомогою системи електронних платежів тощо.

Варто зазначити, що відповідно до Статуту Аграрної біржі, затвердженого постановою Кабінету Міністрів України від 26 грудня 2005 p. № $1285^{28}$, предметом біржової діяльності $\epsilon$, зокрема, належна організація біржових торгів (аукціонів) товарами, товарними деривативами, іпотечними сертифікатами й іпотечними закладними, створення розрахунково-клірингових систем для обслуговування укладених біржових договорів (контрактів). Водночас у ст. 15 Закону України «Про товарну біржу» передбачено, що біржова операція визнається такою лише за умови, що вона являє собою купівлю-продаж, поставку й обмін товарів, допущених до обігу на товарній біржі ${ }^{29}$.

Отже, на Аграрній біржі, яка за сферою своєї діяльності належить до товарної та функціонує з урахуванням ГК України та Закону України «Про товарну біржу» (п. 1 Статуту Аграрної біржі), дозволяється торгівля, крім товарів, також товарними деривативами, іпотечними сертифікатами й іпотечними закладними, які за Законом України «Про цінні папери та фондовий ринок» ${ }^{30} \epsilon$ різновидами цінних паперів.

Поняття «товар», визначення якого міститься в окремих нормативноправових актах, може тлумачитись як у широкому, так i у вузькому розумінні. Однак у більшості законів поняття «товар» визначається в широкому розумінні. Наприклад, у законах України «Про рекламу» ${ }^{31}$, «Про зовнішньоекономічну діяльність» ${ }^{32}$, «Про захист економічної конкуренції» ${ }^{33}$ товар визначається як будь-який предмет господарського обігу, зокрема продукція, роботи, послуги, цінні папери, об'єкти права інтелектуальної власності.

\footnotetext{
${ }^{28}$ Про створення Аграрної біржі : постанова Кабінету Міністрів України від 26 грудня 2005 р. № 1285. URL: https://zakon.rada.gov.ua/laws/show/1285-2005-\%D0\%BF.

${ }^{29}$ Про товарну біржу : Закон України від 10 грудня 1991 р. № 1956-XII. URL: https://zakon.rada.gov.ua/ laws/show/1956-12.

${ }^{30}$ Про цінні папери та фондовий ринок : Закон України від 23 лютого 2006 p. № 3480-IV. URL: https://zakon.rada.gov.ua/laws/show/3480-15.

${ }^{31}$ Про рекламу : Закон України від 3 липня 1996 р. № 270/96-BP. URL: https://zakon.rada.gov.ua/ laws/show/ru/270/96-\%D0\%B2\%D1\%80.

32 Про зовнішньоекономічну діяльність : Закон України від 16 квітня 1991 р. № 959-XII. URL: https://zakon.rada.gov.ua/laws/show/ru/959-12.

33 Про захист економічної конкуренції : Закон України від 11 січня 2001 р. № 2210-III. URL: https://zakon.rada.gov.ua/laws/show/ru/2210-14.
} 
Тобто цінні папери також виступають товаром за умови, що останні беруть участь у господарському обігу. Застосований у Законі України «Про товарну біржу» підхід не дає змоги чітко визначити, який саме товар може бути допущений до торгівлі на товарній біржі. Окрім установлення обмежень, зокрема щодо торгівлі речами, визначеними індивідуальними ознаками, якщо вони не продаються як партія (дві та більше одиниці), а також будь-якими вживаними товарами, зокрема транспортними засобами та капітальними активами, зазначений Закон не містить уточнення стосовно критеріїв, за якими товар може бути допущений до торгівлі на товарній біржі. Тому було б доцільним у ст. 15 Закону України «Про товарну біржу» визначити, які товари, зокрема й цінні папери, можуть бути допущені до торгів на товарній біржі, або встановити критерії, яким такі товари мають відповідати.

У результаті проведеного аналізу положень ГК України, Закону України «Про товарну біржу», які $є$ основними у сфері регулювання біржової торгівлі сільськогосподарською продукцією, можна дійти висновку, що поза сферою правового регулювання залишились такі питання, як організація розрахунків між учасниками торгів, захист учасників торгівлі (гарантії реалізації біржових угод, відповідальність біржі, страхування тощо), державний контроль за діяльністю товарних бірж тощо.

Зокрема, як слушно зазначає щодо цього Є.М. Кирилюк, відсутність ефективного державного контролю та недосконалість нормативноправового забезпечення діяльності бірж призводить до неналежного функціонування біржового ринку в Україні. Науковець зауважує, що координацію біржової торгівлі аграрною продукцією здійснюють органи самоуправління Національної асоціації бірж України (далі - НАБУ) та Союзу аграрних бірж України (далі - САБУ), які передусім обстоюють інтереси бірж. Унаслідок такої ситуації склалась практика порушення контрагентами прийнятих на себе зобов'язань, що виражається у відмові від оформлення укладених під час біржової сесії угод без якихось значних збитків, реєстрація біржою укладених на позабіржовому ринку угод без застосування до них яких-небудь санкцій ${ }^{34}$.

Концепцією розвитку біржового ринку сільськогосподарської продукції визначено організаційну структуру координації біржового ринку, складниками якої мають бути: Державна комісія 3 питань організації біржового сільськогосподарського ринку при Кабінеті Міністрів України; Міністерство агропромислового комплексу (Міністерство аграрної

\footnotetext{
${ }^{34}$ Кирилюк Є.М. Розвиток біржової торгівлі сільськогосподарською продукцією в Україні. Вісник Черкаського університету. 2015. № 12 (345). С. 48.
} 
політики і продовольства України), інші центральні та місцеві органи виконавчої влади; Державний інтервенційний фонд ${ }^{35}$.

Державна комісія з питань організації біржового сільськогосподарського ринку при Кабінеті Міністрів України, до повноважень якої, відповідно до Положення про Державну комісію 3 питань організації біржового сільськогосподарського ринку при Кабінеті Міністрів України, затвердженого постановою Кабінету Міністрів України від 11 квітня 1996 р. № 425 $5^{36}$, належала координація діяльності центральних і місцевих органів державної виконавчої влади, пов'язаної 3 організацією біржового сільськогосподарського ринку, припинила свою діяльність у 2004 р. ${ }^{37}$

Нині в Україні відсутній державний орган, до відання якого входить здійснення координації та контролю за дотриманням законодавства у сфері регулювання біржової торгівлі. Окремі функції в цій сфері продовжує виконувати Міністерство розвитку економіки, торгівлі та сільського господарства України, яке здійснює в межах повноважень, передбачених законом, функції з регулювання товарного біржового ринку i подає Кабінетові Міністрів України узагальнені пропозиції органів виконавчої влади, підприємств, установ та організацій усіх форм власності щодо його вдосконалення; виконує повноваження суб'єкта державного фінансового моніторингу щодо товарних та інших бірж, що проводять фінансові операції з товарами тощо ${ }^{38}$.

Уважаємо, що Закон України «Про товарну біржу» доцільно доповнити розділом, присвяченим здійсненню державного контролю за діяльністю товарних бірж.

Крім того, на відміну від Закону України «Про цінні папери та фондовий ринок» ${ }^{39}$, де визначено, що фондова біржа може створюватися в організаційно-правовій формі акціонерного товариства або товариства 3 обмеженою відповідальністю, ні ГК України, ні Законом України «Про товарну біржу» чітко не встановлено організаційно-правову форму, у якій може утворюватися товарна біржа, не уточнено належність іiі до підприємницьких або непідприємницьких суб'єктів господарювання.

\footnotetext{
35 Про Концепцію розвитку біржового ринку сільськогосподарської продукції : постанова Кабінету Міністрів України № 848 від 5 серпня 1997 p. URL: https://zakon.rada.gov.ua/laws/show/848-97-\%D0\%BF.

${ }^{36}$ Положення Про Державну комісію 3 питань організації біржового сільськогосподарського ринку при Кабінеті Міністрів України : постанова Кабінету Міністрів України від 11 квітня 1996 р. № 425. URL: https://zakon.rada.gov.ua/laws/show/425-96-\%D0\%BF.

${ }^{37}$ Про визнання такими, що втратили чинність, деяких урядових актів : постанова Кабінету Міністрів України від 25 серпня 2004 р. № 1109. URL: https://zakon.rada.gov.ua/laws/show/1109-2004-\%D0\%BF.

${ }^{38}$ Питання Міністерства розвитку економіки, торгівлі та сільського господарства : постанова Кабінету Міністрів України від 11 вересня 2019 р. № 838. URL: https://zakon.rada.gov.ua/laws/show/838-2019$\% \mathrm{D} 0 \% \mathrm{BF}$.

39 Про цінні папери та фондовий ринок : Закон України від 23 лютого 2006 р. № 3480-IV. URL: https://zakon.rada.gov.ua/laws/show/3480-15.
} 
На нашу думку, чітке закріплення організаційно-правової форми, у якій може утворюватися товарна біржа, дасть змогу окреслити особливі вимоги й умови провадження господарської діяльності товарної біржі, встановити обмеження та заборони такої діяльності. Тому в Законі України «Про товарну біржу» варто визначити, що товарна біржа $є$ неприбутковим (непідприємницьким) суб’єктом господарювання.

\section{3. Спеціальні акти господарсько-правового регулювання біржової торгівлі сільськогосподарською продукцісю в Україні}

Деякі спеціальні питання організації та функціонування біржового ринку сільськогосподарської продукції регламентовані Законом України «Про державну підтримку сільського господарства України» ${ }^{40}$, норми якого визначають організований аграрний ринок як сукупність правовідносин, пов'язаних з укладенням та виконанням цивільно-правових договорів, предметом яких $\epsilon$ сільськогосподарська продукція, за стандартизованими умовами та реквізитами біржових договорів (контрактів) і правилами Аграрної біржі.

Крім того, Законом України «Про державну підтримку сільського господарства України» ${ }^{41}$ визначені такі поняття, як «біржовий рахунок», «ризик організованого аграрного ринку», «товарна (біржова) сесія», а також закріплений правовий статус деяких суб'єктів - учасників організованого аграрного ринку, зокрема Аграрного фонду, Аграрної біржі.

Ст. 17 Закону України «Про державну підтримку сільського господарства України» ${ }^{42}$ присвячена організації та функціонуванню аграрних бірж. Зокрема уточнено, що аграрна біржа $є$ неприбутковим підприємством, а для проведення розрахунків за укладеними біржовими угодами (договорами) та надання (обліку та виплати) біржових гарантій Аграрна біржа створює розрахунково-кліринговий центр. Також закріплений порядок здійснення контролю за діяльністю Аграрної біржі, а саме встановлено, що контроль у сфері регулювання та нагляду за операціями продажу товарів на умовах споту та форварду здійснюється Національною комісією, що здійснює державне регулювання у сфері ринків фінансових послуг; у сфері надання кредитних та тваринницьких дотацій - центральним органом виконавчої влади, що реалізує державну політику у сфері казначейського обслуговування бюджетних коштів; у

\footnotetext{
${ }^{40}$ Про державну підтримку сільського господарства України : Закон України від 24 червня 2004 р. № 1877-IV. URL: https://zakon.rada.gov.ua/laws/show/1877-15.

${ }^{41}$ Про державну підтримку сільського господарства України : Закон України від 24 червня 2004 р. № 1877-IV. URL: https://zakon.rada.gov.ua/laws/show/1877-15.

42 Про державну підтримку сільського господарства України : Закон України від 24 червня 2004 р. № 1877-IV. URL: https://zakon.rada.gov.ua/laws/show/1877-15.
} 
сфері загального управління та нагляду - Наглядовою радою Аграрної біржі.

Отже, законодавством України більш детально врегульовані питання організації та здійснення біржової торгівлі сільськогосподарською продукцією, якщо стороною закупівлі виступає держава або якщо така закупівля здійснюється в порядку державної підтримки сільського господарства.

Велике регулятивне значення має також наказ Міністерства економічного розвитку і торгівлі України від 21 листопада 2012 р. № 1327 «Про затвердження Порядку організації та проведення конкурсного відбору товарних бірж для закупівлі матеріальних цінностей до державного матеріального резерву», який визначає процедуру та критерії відбору товарних бірж (електронних біржових майданчиків) для здійснення електронних біржових торгів із закупівлі матеріальних цінностей до державного матеріального резерву Державним агентством резерву України та підприємствами, що належать до сфери його управління, згідно з номенклатурою матеріальних цінностей державного резерву, що затверджується Кабінетом Міністрів України.

Цей порядок визначає поняття електронного біржового майданчика як товарної біржі, яка утворена і здійснює свою діяльність відповідно до Закону України «Про товарну біржу», Господарського кодексу України, правил біржової торгівлі, має програмно-технічні можливості для організації та проведення електронних біржових торгів, забезпечує гарантію виконання зобов'язань за біржовими угодами та контроль за їх виконанням ${ }^{43}$.

Окремі питання організації та здійснення біржової торгівлі сільськогосподарською продукцією визначаються Законом України «Про зерно та ринок зерна в Україні» ${ }^{44}$. Зазначений Закон регламентує правові питання реалізації зерна, що вирощується в Україні або імпортується із-за кордону, зокрема й за допомогою механізмів біржової торгівлі; закріплює вимоги до якості зерна та порядку здійснення державного контролю такої якості; визначає вимоги до зберігання зерна тощо.

Зокрема, відповідно до ст. 13 Закону України «Про зерно та ринок зерна в Україні» ${ }^{45}$, формування обсягів зерна державного продовольчого резерву

\footnotetext{
${ }^{43}$ Про затвердження Порядку організації та проведення конкурсного відбору товарних бірж для закупівлі матеріальних цінностей до державного матеріального резерву : наказ Міністерства економічного розвитку i торгівлі України від 21 листопада 2012 p. № 1327. URL: https://zakon.rada.gov.ua/laws/show/z2070-12.

${ }_{44}$ Про зерно та ринок зерна в Україні : Закон України від 4 липня 2002 р. № 37-IV. URL: https://zakon.rada.gov.ua/laws/show/37-15.

45 Про зерно та ринок зерна в Україні : Закон України від 4 липня 2002 р. № 37-IV. URL: https://zakon.rada.gov.ua/laws/show/37-15.
} 
здійснюється Аграрним фондом шляхом укладання угод купівлі-продажу на аграрній біржі, а порядок його використання визначається законодавством.

Механізм проведення Аграрним фондом державних форвардних закупівель зерна з метою формування державного інтервенційного фонду визначається Порядком проведення державних форвардних закупівель зерна, затвердженим постановою Кабінету Міністрів України від 16 травня 2007 p. № 736 (у редакції постанови Кабінету Міністрів України від 24 вересня 2012 р. № 879) ${ }^{46}$. Цим Порядком передбачено, що Аграрний фонд проводить форвардні закупівлі за кошти, передбачені в державному бюджеті України на відповідний рік, шляхом укладення на Аграрній біржі між Аграрним фондом та товаровиробником контракту, форма якого затверджується Мінекономіки.

Варто зазначити, що господарське законодавство лише в загальних рисах регулює порядок організації та діяльності товарних бірж щодо торгівлі сільськогосподарською продукцією. Оскільки товарна біржа $є$ суб'єктом господарювання, то детальне регулювання здійснюється в локальних актах, які ухвалюються біржою самостійно.

Крім статуту, товарна біржа, відповідно до ст. 17 Закону України «Про товарну біржу», обов'язково розробляє Правила біржової торгівлі, які мають визначати: строк і місце проведення біржових операцій; склад учасників біржових торгів і сукупність вимог, що ставляться до них; порядок здійснення та реєстрації біржових операцій; порядок визначення та розмір плати за користування послугами біржі; відповідальність учасників та працівників біржі за невиконання або неналежне виконання правил біржової торгівлі ${ }^{47}$.

\section{ВИСНОВКИ}

Сучасний стан правового регулювання біржової торгівлі сільськогосподарською продукцією в Україні характеризується недостатньою ефективністю, відсутністю системного підходу до регулювання біржової діяльності. Також мають місце суттєві прогалини та недоліки господарського законодавства в цій сфері, які виражаються в неврегульованості таких важливих питань, як механізм здійснення біржової торгівлі сільськогосподарською продукцією, система розрахунків між учасниками торгівлі, гарантії захисту прав та інтересів учасників торгів тощо. Деякі із цих питань урегульовані Законом України «Про

\footnotetext{
46 Про запровадження державних форвардних закупівель зерна : постанова Кабінету Міністрів України від 16 травня 2007 p. № 736. URL: https://zakon.rada.gov.ua/laws/show/736-2007-\%D0\%BF\#n14.

47 Про товарну біржу : Закон України від 10 грудня 1991 p. № 1956-XII. URL: https://zakon.rada.gov.ua/laws/show/1956-12.
} 
державну підтримку сільського господарства України» щодо діяльності Аграрної біржі, однак, зважаючи на те, що торгівля сільськогосподарською продукцією здійснюється не тільки через Аграрну біржу, але також і через інші товарні (комплексні) біржі, упорядкування потребують господарські правовідносини, які виникають щодо торгівлі сільськогосподарською продукцією на інших товарних біржах.

Для вдосконалення господарського законодавства в цій сфері передусім необхідно в Господарському кодексі України, Законі України «Про товарні біржі» визначити порядок та спосіб здійснення розрахунків між учасниками торгів, організацію та засоби захисту учасників торгівлі (гарантії реалізації біржових угод, відповідальність біржі, страхування тощо), порядок здійснення державного контролю за діяльністю товарних бірж тощо. Також потребує оновлення Концепція розвитку біржового ринку сільськогосподарської продукції з урахуванням новітніх світових підходів та розвитку біржового ринку, міжнародних засад регулювання біржової торгівлі, запровадження новітніх технологій укладення біржових угод та здійснення розрахунків.

\section{АНОТАЦІЯ}

Роботу присвячено проведенню аналізу міжнародного та національного законодавства у сфері регулювання біржової торгівлі сільськогосподарською продукцією. Охарактеризовано зміст міжнародно-правових актів у досліджуваній сфері, встановлено міжнародні зобов'язанні, прийняті Україною щодо розвитку сільського господарства. Зроблено висновок про те, що міжнародні акти у сфері регулювання торгівлі сільськогосподарською продукцією визначають міжнародні стандарти, що висуваються до якості сільськогосподарської продукції.

Проведено аналіз актів національного господарського законодавства, що регулює біржову торгівлю сільськогосподарською продукцією. Обгрунтовано думку про те, що господарське законодавство України $\epsilon$ більш ефективним у питаннях регулювання організації та здійснення біржової торгівлі сільськогосподарською продукцією, якщо стороною закупівлі виступає держава або якщо така закупівля здійснюється в порядку державної підтримки сільського господарства.

Виявлено законодавчі прогалини та недоліки, які перешкоджають розвитку організованого ринку біржової торгівлі сільськогосподарською продукцією. Визначено основні напрями вдосконалення господарського законодавства в досліджуваній сфері. 


\section{ЛІТЕРАТУРА}

1. The development role of commodity exchanges : United Nations Conference on Trade and Development TD/B/COM.1/EM.33/2. 25 June 2007. URL: https://unctad.org/en/Docs/c1em33d2_en.pdf.

2. Господарський кодекс України від 16 січня 2003 р. № 436-IV. URL: https://zakon.rada.gov.ua/laws/show/436-15.

3. Деякі питання Аграрної біржі : постанова Кабінету Міністрів України від 24 лютого 2010 р. № 196. URL: https://zakon.rada.gov.ua/laws/show/1962010-\%D0\%BF.

4. Директива Ради 2000/29/€С про заходи захисту від інтродукції на територію Спільноти організмів, шкідливих для рослин або рослинних продуктів, та від їхнього поширення на території Спільноти, зі змінами, внесеними зазначеними нижче Директивами (преамбула пропущена), від 8 травня 2000 p. OB № L169. 10.07.2000. C. 1-112. URL: http://www.fitolab.volyn.ua/images/direktivy.pdf.

5. Кирилюк Є.М. Розвиток біржової торгівлі сільськогосподарською продукцією в Україні. Вісник Черкаського університету. 2015. № 12 (345). C. $46-53$.

6. Лебеденко В.І. Господарське законодавство: комплексний сегментарний інститут господарського права. Науковий вісник Міжнародного гуманітарного університету. Серія «Юриспруденція». 2013. № 6-2. Т. 2. C. 24-27.

7. Міжнародна конвенція про захист рослин від 6 грудня 1951 p. URL: https://zakon.rada.gov.ua/laws/show/995_805.

8. Питання Міністерства розвитку економіки, торгівлі та сільського господарства : постанова Кабінету Міністрів України від 11 вересня 2019 p. № 838. URL: https://zakon.rada.gov.ua/laws/show/838-2019-\%D0\%BF.

9. Положення про Державну комісію 3 питань організації біржового сільськогосподарського ринку при Кабінеті Міністрів України : постанова Кабінету Міністрів України від 11 квітня 1996 p. № 425. URL: https://zakon.rada.gov.ua/laws/show/425-96-\%D0\%BF.

10. Про визнання такими, що втратили чинність, деяких урядових актів : постанова Кабінету Міністрів України від 25 серпня 2004 р. № 1109. URL: https://zakon.rada.gov.ua/laws/show/1109-2004-\%D0\%BF.

11. Про державну підтримку сільського господарства України : Закон України від 24 червня 2004 p. № 1877-IV. URL: https://zakon.rada.gov.ua/ laws/show/1877-15.

12. Про додаткові заходи щодо стабілізації ринку зерна : Указ Президента України від 19 травня 2003 р. № 415/2003. URL: https://zakon.rada.gov.ua/laws/show/415/2003. 
13. Про запровадження державних форвардних закупівель зерна : постанова Кабінету Міністрів України від 16 травня 2007 р. № 736. URL: https://zakon.rada.gov.ua/laws/show/736-2007-\%D0\%BF\#n14.

14. Про затвердження Порядку організації та проведення конкурсного відбору товарних бірж для закупівлі матеріальних цінностей до державного матеріального резерву : наказ Міністерства економічного розвитку і торгівлі України від 21 листопада 2012 р. № 1327. URL: https://zakon.rada.gov.ua/laws/show/z2070-12.

15. Про захист економічної конкуренції : Закон України від 11 січня 2001 p. № 2210-III. URL: https://zakon.rada.gov.ua/laws/show/ru/2210-14.

16. Про заходи щодо забезпечення формування та функціонування аграрного ринку : Указ Президента України від 6 червня 2000 р. № 767/2000. URL: https://zakon.rada.gov.ua/laws/show/767/2000.

17. Про заходи щодо прискорення розвитку аграрного ринку : Указ Президента України від 8 серпня 2002 р. № 694/2002. URL: https://zakon.rada.gov.ua/laws/show/694/2002.

18. Про зерно та ринок зерна в Україні : Закон України від 4 липня 2002 p. № 37-IV. URL: https://zakon.rada.gov.ua/laws/show/37-15.

19. Про зовнішньоекономічну діяльність : Закон України від 16 квітня 1991 p. № 959-XII. URL: https://zakon.rada.gov.ua/laws/show/ru/959-12.

20. Про Концепцію розвитку біржового ринку сільськогосподарської продукції : постанова Кабінету Міністрів України від 5 серпня 1997 р. № 848. URL: https://zakon.rada.gov.ua/laws/show/848-97-\%D0\%BF.

21. Про особливості страхування сільськогосподарської продукції 3 державною підтримкою : Закон України від 9 лютого 2012 р. № 4391-VI. URL: https://zakon.rada.gov.ua/laws/show/4391-17.

22. Про приєднання України до Міжнародної конвенції про захист рослин : Указ Президента України від 31 січня 2006 р. № 81/2006. URL: https://zakon.rada.gov.ua/laws/show/81/2006.

23. Про прискорення організації біржового сільськогосподарського ринку : постанова Кабінету Міністрів України від 17 листопада 1995 р. № 916. URL: https://zakon.rada.gov.ua/laws/show/916-95-\%D0\%BF.

24. Про рекламу : Закон України від 3 липня 1996 р. № 270/96-BP. URL: https://zakon.rada.gov.ua/laws/show/ru/270/96-\%D0\%B2\%D1\%80.

25. Про створення Аграрної біржі : постанова Кабінету Міністрів України від 26 грудня 2005 р. № 1285. URL: https://zakon.rada.gov.ua/ laws/show/1285-2005-\%D0\%BF.

26. Про схвалення Концепції Державної цільової програми розвитку аграрного сектора економіки на період до 2022 р. : розпорядження 
Кабінету Міністрів України від 30 грудня 2015 р. № 1437-p. URL: http://zakon3.rada.gov.ua/laws/show/1437-2015-\%D1\%80.

27. Про товарну біржу : Закон України від 10 грудня 1991 р. № 1956XII. URL: https://zakon.rada.gov.ua/laws/show/1956-12.

28. Про цінні папери та фондовий ринок : Закон України від 23 лютого 2006 p. № 3480-IV. URL: https://zakon.rada.gov.ua/laws/show/3480-15.

29. Угода про асоціацію між Україною, 3 однієї сторони, та Європейським Союзом, Свропейським співтовариством з атомної енергії і їхніми державами-членами, з іншої сторони, від 27 червня 2014 р. URL: https://zakon.rada.gov.ua/laws/show/984_011.

30. Угода про застосування санітарних та фітосанітарних заходів від 15 квітня 1994 p. URL: http://zakon5.rada.gov.ua/laws/show/981_006.

31. Угода про сільське господарство від 15 квітня 1994 p. URL: https://zakon.rada.gov.ua/laws/show/981_005.

Information about author:

Bondarchuk A. N.,

Lawyer

Lavrynovych \& Partners Law Firm LLC 41, Saksaganskogo str., Kyiv, Ukraine 